\title{
Pendidikan Karakter Berbasis Kurikulum Terintegrasi di Perguruan Tinggi Agama Islam
}

\author{
Khalid Rahman \\ ${ }^{1}$ Universitas Brawijaya Malang
}

Keywords:

Character building, Integrated

Curriculum, Islamic University

*Correspondence Address:
tlq@ub.ac.id

\begin{abstract}
This study departs from an integrated curriculum problem in higher education which has not found a clear formulation according to the direction of character formation. In the integrated curriculum, there is a comprehensive model to the practical level to shape the character of students. Today's universities are almost having trouble producing graduates with character. The integrated curriculum offers an integrated and complex educational concept in developing student potential. With the character education model based on an integrated curriculum, it is hoped that it will be a solution to the concerns of education practitioners facing the decline in the character of higher education graduates. This paper explains that: (1) The concept of integrated curriculum-based character education carried out in tertiary institutions consists of the conception of an integrated vision and mission, institutional integration, curriculum integration, and learning according to the model both within single disciplines, across several disciplines, and inside the mind. of the learners; (2) Integrated curriculum-based character education uses a rational and deductive interaction approach to divide roles between leaders, employees, and lecturers; (3) methods and strategies in integrated curriculum-based character education in the classroom, by prioritizing problem-solving methods, project methods, unit teaching, inquiry, discovery, and thematic approaches; (4) evaluation of integrated curriculum-based character education.
\end{abstract}

\begin{abstract}
Abstrak: Kajian ini berangkat dari sebuah persoalan kurikulum terintegrasi di perguruan tinggi yang belum menemukan formulasinya secara jelas sesuai arah pembentukan karakter. Dalam kurikulum terintegrasi terdapat model yang komprehensif hingga pada tataran praktis untuk membentuk karakter mahasiswa. Perguruan tinggi saat ini hampir kesulitan melahirkan lulusan yang berkarakter. Dengan adanya model pendidikan karakter yang berbasis kurikulum terintegrasi, harapannya mampu menjadi solusi keresahan para praktisi pendidikan menghadapi kemerosotan karakter lulusan pendidikan tinggi. Artikel ini menjelaskan bahwa: (1) Konsep pendidikan karakter berbasis kurikulum terintegrasi yang dilakukan di Perguruan Tinggi, terdiri dari konsepsi visi dan misi terintegrasi, integrasi kelembagaan, integrasi kurikulum dan pembelajaran sesuai modelnya baik within single disciplines, across several disciplines, dan inside the mind of the learner; (2) Pendidikan karakter berbasis kurikulum terintegrasi menggunakan pendekatan interaksi rasional dan rasional deduktif untuk membagi peran antara pimpinan, karyawan dan dosen; (3) metode dan strategi dalam pendidikan karakter berbasis kurikulum terintegrasi di kelas, dengan mengedepankan metode problem solving, metode proyek, pengajaran unit, inquiry, discovery, dan pendekatan tematik; (4) evaluasi pendidikan karakter berbasis kurikulum terintegrasi.
\end{abstract}





\section{PENDAHULUAN}

Pendidikan karakter bukanlah sesuatu yang baru dibicarakan, namun kejayaan suatu bangsa dan negara tercermin dari karakter yang dimiliki warganya. Begitu pentingnya karakter, sejak berdirinya negara Indonesia kemudian era pembangunan dan era reformasi, karakter adalah tolak ukur ekspresi Sumber Daya Manusia Indonesia apakah sudah mencapai kemakmuran yang dicita-citakan bangsa dan negara, atau masih jauh panggang dari api. Di era awal, saat diproklamasikan kemerdekaan Indonesia tanggal 17 Agustus 1945, bapak pendiri bangsa (the founding fathers) menyadari bahwa paling tidak ada tiga tantangan besar yang harus dihadapi. Pertama, mendirikan Negara yang bersatu dan berdaulat, kedua, membangun bangsa, dan ketiga, membangun karakter. ${ }^{1}$

Karakter adalah sesuatu yang sangat penting dan vital bagi tercapainya tujuan hidup. Karakter merupakan dorongan pilihan untuk menentukan yang terbaik dalam hidup. Sebagai bangsa Indonesia setiap dorongan pilihan itu harus dilandasi oleh Pancasila. Sementara itu sudah menjadi fitrah bangsa Indonesia untuk menjadi bangsa yang multi suku, multi ras, multi bahasa, multi adat, dan tradisi. Untuk tetap menegakkan Negara Kesatuan Republik Indonesia maka kesadaran untuk menjunjung tinggi Bhinneka Tunggal Ika merupakan suatu condition sine quanom, syarat mutlak yang tidak dapat ditawar-tawar lagi, karena

1 Muchlas Samani dan Hariyanto, Konsep dan Model Pendidikan Karakter, (Bandung: PT Remaja Rosdakarya, 2011), 1 pilihan lainnya adalah runtuhnya Negara ini. ${ }^{2}$

Pentingnya karakter bagi seluruh rakyat Indonesia, sebagaimana dalam Undang-undang Sistem Pendidikan Nasional menegaskan bahwa pendidikan nasional berfungsi mengembangkan kemampuan dan membentuk watak serta peradaban bangsa yang bermartabat dalam rangka mencerdaskan kehidupan bangsa, bertujuan untuk berkembangnya potensi peserta didik agar menjadi manusia yang beriman dan bertakwa kepada Tuhan yang Maha Esa, berakhlak mulia, sehat, berilmu, cakap, kreatif, mandiri dan menjadi warga Negara yang demokratis serta bertanggung jawab.

Dimana seharusnya pendidikan yang dilakukan di negara Indonesia mengarah pada penanaman karakter, pembinaan dan pengembangan yang menempa watak yang beradab, cerdas, berakhlak, berilmu, sehat, cakap, kreatif, mandiri dan tanggung jawab, bukan pendidikan yang menghasilkan lulusan yang cengeng serba instan, bermoral rendah dan tidak memiliki daya juang yang tangguh. Inti pendidikan adalah penempaan diri pada karakter atau watak yang siap menghadapi segala persoalan hidup dan problem bangsa dan negara dengan tangguh dan cakap. Oleh sebab itu, sudah secepatnya perguruan tinggi sebagai institusi terakhir pemberi bekal pada generasi emas bangsa untuk menanamkan, membekali dan mempatri karakter yang beradab, cakap, tangguh, patriotik untuk siap membangun kemakmuran bangsa dan negara.

Pendidikan karakter di perguruan tinggi akan berjalan dengan baik bila terjalin dengan

2 Samani dan Hariyanto, Konsep dan Model, 1 
pengembangan kurikulum terintegrasi. Selama ini kurikulum yang berjalan di perguruan tinggi lebih nampak parsial, seolah-olah perguruan tinggi hanya mengurusi perkembangan otak/ pikiran mahasiswa, sedangkan persoalan moral susila, agama, adat dan hukum menjadi urusan masingmasing mahasiswa. Sehingga mata kuliah yang bermuatan moral susila dan pancasila, maupun agama sekedar menjadi pelengkap kurikulum titipan negara. Sudah pasti gagal pembentukan karakter mahasiswa hanya dibebankan pada dosen pelengkap kurikulum nasional. Karakter akan terbentuk secara komprehensif bila seluruh mata kuliah diajarkan dan dididikkan nilai-nilainya pada mahasiswa sebagai acuan berperilaku dalam kehidupannya. Bukan sekedar nilai yang terpisah, apalagi nilai yang cuma di atas kertas untuk menjelaskan kemampuan otak/pikiran dan pemahaman mahasiswa. Hal demikian, tidak akan berarti bila mental mahasiswa tetap tidak berkarakter atau berwatak tangguh, kerja keras, jujur, disiplin dan berdaya juang untuk hidup lebih baik, karena kehidupan tidak semudah tertulis di atas kertas kurikulum yang cenderung cognitive minded. Di sinilah penulis menawarkan kurikulum terintegrasi sebagai sarana pembentukan karakter mahasiswa ketika di perguruan tinggi dan harapannya tetap menjadi bekal dalam kehidupannya.

\section{METODE}

Peneliti menggunakan penelitian kepustakaan (Library Research). Yaitu penelitian yang dilakukan dengan memanfaatkan literatur (kepustakaan), seperti buku, catatan, maupun laporan hasil penelitian terdahulu. Teknik pengumpulan data dengan menelaah literatur yang berhubungan dengan kajian yang peneliti kaji dalam artikel ini yaitu pendidikan karakter.

\section{HASIL DAN PEMBAHASAN}

\section{Konsep Pendidikan Karakter Berbasis Kurikulum Terintegrasi}

Karakter dimaknai sebagai cara berpikir dan berperilaku yang khas tiap individu untuk hidup dan bekerjasama, baik dalam lingkup keluarga, masyarakat, bangsa dan Negara. Karakter dapat dianggap sebagai nilai-nilai perilaku manusia yang berhubungan dengan Tuhan Yang Maha Esa, diri sendiri, sesama manusia, lingkungan, dan kebangsaan yang terwujud dalam pikiran, sikap, perasaan, perkataan dan perbuatan berdasarkan norma-norma agama, hukum, tata krama, budaya, adat istiadat dan estetika. ${ }^{3}$

Pada Kamus Besar Bahasa Indonesia karakter merupakan sifatsifat kejiwaan, akhlak atau budi pekerti yang membedakan seseorang dengan yang lain. Dengan demikian karakter adalah nilai-nilai yang unik baik yang terpatri dalam diri dan terejawantahkan dalam perilaku Jadi pendidikan karakter adalah proses pemberian tuntunan kepada mahasiswa untuk menjadi manusia seutuhnya yang berkarakter dalam dimensi hati, pikir, raga, serta rasa dan karsa. Pendidikan karakter dapat dimaknai sebagai pendidikan nilai, pendidikan budi pekerti, pendidikan moral, pendidikan watak, yang bertujuan mengembangkan kemampuan peserta didik untuk memberikan keputusan baik-buruk, memelihara apa yang baik, dan mewujudkan kebaikan itu dalam

\footnotetext{
${ }^{3}$ Samani dan Hariyanto, Konsep dan Model, 42
} 
kehidupan sehari-hari dengan sepenuh hati. ${ }^{4}$

Berdasarkan definisi yang dipaparkan di atas, istilah karakter dapat dilihat dari dua sudut pandang. Pertama, dari sisi sifat dinamikanya yang bersifat given, bawaan lahir ataukah terus akan mengalami perubahan seiring dengan berubahnya lingkungan sosial dan budaya. Kedua, jika dilihat dari sisi implementasi, maka akan muncul dua pilihan, menjadi subjek yang otonom, individu yang mempunyai kesadaran, kebebasan bertanggung jawab ataukah hanya menerima model penanaman karakter yang bercorak intervensi. ${ }^{5}$ Maka pendidikan karakter adalah usaha sadar manusia untuk mengembangkan keseluruhan dinamika relasional antar pribadi dengan berbagai macam dimensi, baik dari dalam maupun dari luar dirinya, agar pribadi itu semakin terbentuk menjadi individu yang paripurna (insan kamil) baik melalui ruang kebebasan yang diberikan ataupun intervensi moral/karakter yang dilakukan oleh lembaga pendidikan tertentu. ${ }^{6}$

Kaitan sikap dan perilaku budi pekerti mengandung lima jangkauan sebagai berikut: (1) sikap dan perilaku dalam hubungannya dengan Tuhan, (2) sikap dan perilaku dalam hubungannya dengan diri sendiri, (3) sikap dan perilaku dalam hubungannya dengan keluarga, (4) sikap dan perilaku dalam hubungannya dengan masyarakat dan

\footnotetext{
4 Samani dan Hariyanto, Konsep dan Model, 46

5 Mohamad Anas, et.all, Berkepribadian dalam Kebudayaan Indonesia, (Malang: PMPK UB, 2020), 30

${ }^{6}$ Dony Koesoema A., Pendidikan Karakter, Utuh dan Menyeluruh, (Yogyakarta: Kanisius, 2015), 57
}

bangsa, (5) sikap dan perilaku dalam hubungannya dengan alam sekitar.

\section{Tabel 1. Jangkauan Sikap dan Perilaku dan Butir-butir Nilai Budi Pekerti}

\section{Jangkauan Sikap
dan Perilaku Butir-butir Nilai Budi Pekerti \\ Sikap dan Berdisiplin, beriman, bertakwa,} perilaku dalam hubungannya berpikir jauh ke depan, dengan Tuhan bersyukur, jujur, mawas diri, pemaaf, pemurah, pengabdian.

Sikap dan perilaku dalam hubungannya dengan diri sendiri

Sikap dan perilaku dalam hubungannya dengan keluarga perilaku dalam hubungannya dengan masyarakat dan bangsa

Sikap dan perilaku dalam hubungannya dengan alam sekitar Bekerja keras, berani memikul resiko, berdisiplin, berhati lembut/berempati, berpikir matang, berpikir jauh ke depan/visioner, bersahaja, bersemangat, bersifat konstruktif, bertanggung jawab, bijaksana, cerdik, cermat, dinamis, efisien, gigih, hemat, jujur, berkemauan keras, kreatif, kukuh hati, lugas, mandiri, mawas diri, menghargai karya orang lain, menghargai kesehatan, menghargai waktu, pemaaf, pemurah, pengabdian, pengendalian diri, produktif, rajin, ramah tamah, rasa kasih sayang, rasa percaya diri, rela berkorban, sabar, setia, adil, hormat, tertib, sportif, susila, tangguh, tegas, tekun, tepat janji/amanah, terbuka, ulet. Bekerja keras, berpikir jauh ke depan, bijaksana, cerdik, cermat, jujur, berkemauan keras, lugas, menghargai kesehatan, menghargai waktu, tertib, pemaaf, pemurah, pengabdian, ramah tamah, rasa kasih sayang, rela berkorban, sabar, setia, adil, hormat, sportif, susila, tegas, tepat janji, terbuka.

Bekerja keras, berpikir jauh ke depan, bertenggang rasa/toleran, bijaksana, cerdik, cermat, jujur, berkemauan keras, lugas, setia, menghargai kesehatan, menghargai waktu, pemurah, pengabdian, ramah tamah, rasa kasih sayang, rela berkorban, adil, hormat, tertib, sportif, susila, tegas, tepat janji/amanah, terbuka.

Bekerja keras, berpikir jauh ke depan, menghargai kesehatan, pengabdian, menjaga kebersihan, merawat alam, bersahabat dengan alam. 
Sedangkan Kurikulum terintegrasi sebagai pendekatan yang merespon terhadap perkembangan masyarakat yang menuntut model-model pengetahuan yang lebih komprehensif dan terpadu. Kurikulum terintegrasi merupakan kurikulum yang mampu menciptakan kesatuan perilaku bukan saja yang bersifat intelektual, tetapi juga emosional dan tindakan, sehingga mahasiwa akan mampu menerima pengalaman yang menyeluruh bukan pengalaman yang terpenggal-penggal. ${ }^{7}$ Di sinilah menjadi titik tolak pendidikan karakter yang akan mungkin berjalan dengan baik bila kurikulum yang dikembangkan adalah kurikulum terintegrasi, karena kurikulum ter-integrasi mengarahkan terciptanya kesatuan perilaku baik intelektual, emosional dan tindakan sehingga kerangka kualifikasi kompetensi mahasiswa akan tercapai dengan baik.

Kurikulum terintegrasi (integrated curriculum) lebih memandang bahwa dalam suatu pokok bahasan harus terpadu secara menyeluruh. Keterpaduan ini dapat dicapai melalui pemusatan matakuliah pada satu masalah tertentu dengan alternatif pemecahan melalui berbagai disiplin ilmu atau matakuliah yang diperlukan. ${ }^{8}$ Dengan adanya kebulatan bahan ajar dalam perkuliahan, dapat terbentuk kebulatan kepribadian mahasiswa yang sesuai dengan lingkungan masyarakatnya. ${ }^{9}$

7 Nana Syaodih Sukmadinata, Pengembangan Kurikulum: Teori dan Praktek, (Bandung: PT. Remaja Rosdakarya, 2005), 90

8 Muhammad Ali, Pengembangan Kurikulum di Sekolah, (Bandung: Sinar Baru Algensindo, 2009), 58

9 Burhan Nurgiyantoro, Dasar-dasar Pengembangan Kurikulum Sekolah, (Yogyakarta: BPFE, 1988), 119
Kurikulum

terintegrasi

memberikan kesempatan pada mahasiswa untuk belajar secara kelompok maupun secara individu, lebih memberdayakan masyarakat sebagai sumber belajar, memungkinkan pembelajaran bersifat individu terpenuhi, serta dapat melibatkan mahasiswa dalam mengembangkan program pembelajaran. Sehingga mahasiswa diperbolehkan mengusulkan topik persoalan yang akan dikaji dalam perkuliahan, karena diri dan pengalaman mahasiswa adalah sebagai sumber bahan ajar. Bahan ajar akan selalu aktual sesuai perkembangan dan kebutuhan masyarakat maupun mahasiswa sebagai individu yang utuh sehingga bahan ajar yang dipelajari selalu sesuai dengan bakat, minat, dan potensi mahasiswa. ${ }^{10}$ Kurikulum ini juga mempertimbangkan semua aspek, sesuai dengan sistem kepercayaan, sistem nilai, sistem kebutuhan yang terpadu dalam masyarakat, sehingga pembentukan moral dan karakter mahasiswa akan berjalan seiringan dengan norma-norma dan spirit masyarakat.

Menurut Tianto, model kurikulum terintegrasi dikelompokkan menjadi 3 (tiga) klasifikasi pengintegrasian kurikulum, sebagai berikut: ${ }^{11}$

1. Pengintegrasian di dalam Satu Disiplin Ilmu

Model ini merupakan integrasi yang mentautkan dua atau lebih bidang ilmu yang serumpun. Misalnya di bidang Ilmu Alam, mentautkan antara dua tema dalam fisika dan biologi yang memiliki relevansi, atau

10 Rusman, Manajemen Kurikulum, (Jakarta: PT RajaGrafindo Persada, 2009), 65

11 Trianto, Model Pembelajaran Terpadu: Teori dan Praktek, (Jakarta: Prestasi Pustaka, 2007), 40 
antara tema dalam kimia dan fisika. Contoh: tema metabolisme dapat ditinjau dari biologi maupun kimia. Begitupun dengan tema-tema yang relevan pada Ilmu Sosial seperti antara sosiologi dan geografi. Jadi sifat perpaduan dalam model ini hanya dalam satu rumpun bidang ilmu saja (inter-disipliner).

\section{Pengintegrasian Beberapa Disiplin} Ilmu

Model ini merupakan integrasi yang mentautkan antar disiplin ilmu yang berbeda. Misalnya antara tema yang ada dalam bidang ilmu sosial dengan bidang ilmu alam. Sebagai contoh, tema energi merupakan tema yang dapat dikaji dari bidang ilmu yang berbeda baik dalam bidang ilmu sosial (tentang kebutuhan energi dalam masya-rakat), dan bidang ilmu alam (tentang bentuk-bentuk energi dan teknologinya). Jadi model ini, suatu tema tertentu dapat dikaji dari dua sisi bidang ilmu yang berbeda (antardisiplin ilmu).

3. Pengintegrasian di dalam Satu dan Beberapa Disiplin Ilmu

Model ini merupakan integrasi yang paling kompleks karena mentautkan antar disiplin ilmu yang serumpun sekaligus bidang ilmu yang berbeda. Misalnya, antara tema yang ada dalam bidang ilmu sosial, bidang ilmu alam, teknologi maupun ilmu agama. Sebagai contoh, tema rokok merupakan tema yang dapat dikaji dari berbagai bidang ilmu yang berbeda.

Di bidang ilmu sosial dapat dikaji dampak sosial merokok dalam masyarakat (sosiologi), dan aspek pembiayaan ekonomi bagi perokok (ekonomi). Dalam bidang ilmu alam, dapat dikaji bahaya rokok bagi kesehatan (biologi), kandungan kimia rokok (kimia), unsur radio aktif dalam daun tembakau (fisika). Sedangkan di bidang ilmu agama dapat dikaji bahwa merokok merupakan perbuatan yang sia-sia (makruh hukumnya). Dengan demikian pembelajaran yang dilaksanakan akan semakin bermakna, karena pada dasarnya tidak satupun permasalahan (konsep) yang dapat ditinjau hanya dari satu sisi saja.

Tabel 2. Klasifikasi Pengintegrasian Kurikulum ${ }^{12}$

\begin{tabular}{|c|c|c|}
\hline No. & $\begin{array}{l}\text { Klasifikasi } \\
\text { Pengintegrasian }\end{array}$ & $\begin{array}{c}\text { Model Kurikulum } \\
\text { Terintegrasi }\end{array}$ \\
\hline 1) & $\begin{array}{l}\text { Pengintegrasian } \\
\text { kurikulum di dalam } \\
\text { satu disiplin ilmu } \\
\text { (interdisiplin ilmu) }\end{array}$ & $\begin{array}{l}\text { The Cellular model (model } \\
\text { tergambarkan), } \\
\text { connected model (model } \\
\text { terhubung), the nested } \\
\text { model (model bersarang) }\end{array}$ \\
\hline 2) & $\begin{array}{l}\text { Pengintegrasian } \\
\text { kurikulum beberapa } \\
\text { disiplin ilmu (antar } \\
\text { disiplin ilmu) }\end{array}$ & $\begin{array}{l}\text { The squenced model } \\
\text { (model terurut), the } \\
\text { shared model (model } \\
\text { terbagi), the webbed model } \\
\text { (model terjaring), the } \\
\text { threaded model (model } \\
\text { tertali), the integrated } \\
\text { model (model terpadu) }\end{array}$ \\
\hline 3) & $\begin{array}{l}\text { Pengintegrasian } \\
\text { kurikulum di dalam } \\
\text { dan beberapa } \\
\text { disiplin ilmu (inter } \\
\text { dan antar disiplin } \\
\text { ilmu) }\end{array}$ & $\begin{array}{l}\text { The immersed model } \\
\text { (model terbenam), the } \\
\text { networked model (model } \\
\text { jaringan) }\end{array}$ \\
\hline
\end{tabular}

\section{Pelaksanaan Pendidikan Karakter Berbasis Kurikulum Terintegrasi}

Pendidikan karakter yang dilaksanakan dengan basis kurikulum terintegrasi harus memperhatikan model pelaksanaannya yang berangkat dari perencanaan manajerial yang telah disusun. Apakah model perencanaan manajerial berbentuk rasional deduktif, yang menitikberatkan logika dalam merancang program kurikulum dan bertitik-tolak dari spesifikasi tujuan, tetapi cenderung mengabaikan problematika dalam lingkungan dan tugas. Bila bentuknya demikan, maka kurikulum terintegrasi yang disusun untuk pendidikan karakter hanya cocok untuk mengukur capaian secara generalistik. Karena kasus-kasus kecil

12 Trianto, Model Pembelajaran Terpadu, 42 
yang muncul dipermukaan mahasiswa cenderung terabaikan dan akan dicover dengan tujuan kurikulum terintegrasi yang cakupannya lebih luas, sehingga problem pendidikan karakter tetap akan teratasi.

Bila model interaktif rasional yang digunakan dalam pengembangan kurikulum terintegrasi dalam pendidikan karakter, yang lebih memandang rasionalitas sebagai tuntutan kesepakatan antara pendapat-pendapat yang berbeda dalam perumusan tujuan pembelajaran, yang tidak mengikuti urutan logik. Model ini juga dinamakan model situasional, asumsi rasionalitasnya menekankan pada respons fleksibel kurikulum yang tidak memuaskan dan inisiatif pada tingkat dosen atau tingkat pembelajar. Implementasinya diperlukan daya beradaptasi yang tinggi, karena dosen harus memiliki wawasan yang luas, multidisiplin dan cross-disiplin antara perencana dan pelaksanaan kurikulum terintegrasi dalam pendidikan karakter.

\section{Metode dan Strategi dalam Pendidikan Karakter Berbasis Kurikulum Terintegrasi}

Kaitannya dengan kurikulum terintegrasi, strategi yang umum dilaksanakan adalah mengintegrasikan pendidikan karakter dalam bahan ajar. Menurut Samani dan Hariyanto strategi pelaksanaan pendidikan karakter antara lain: (1) strategi pemanduan (cheerleading), (2) pujian dan hadiah (praise and reward), (3) definisikan dan latihkan (define and drill), (4) penegakan disiplin (forced formality), (5) perangai bulan ini (traits of the month). ${ }^{13}$

13 Samani dan Hariyanto, Konsep dan Model, 144
Menurut

Sukmadinata pengembangan kurikulum terintegrasi prosesnya, sebagai berikut: 14

1. Menentukan tema-tema (topik) yang membentuk satu kesatuan (unifying theme), yang dapat terdiri atas ide atau konsep besar yang dapat mencakup semua ilmu atau suatu proses kerja ilmu, fenomena alam, atau masalah sosial yang membutuhkan pemecahan secara ilmiah.

2. Menyatukan kegiatan belajar dari beberapa disiplin ilmu. Kegiatan belajar melibatkan isi dan proses dari satu atau beberapa ilmu sosial atau perilaku yang mempunyai hubungan dengan tema yang dipilih/dikerjakan.

3. Menyatukan beberapa cara atau metode belajar. Kegiatan belajar ditekankan pada pengalaman konkret yang bertolak dari minat dan kebutuhan mahasiswa serta disesuaikan dengan keadaan setempat.

Sedangkan pendekatan yang digunakan dalam pelaksanaan kurikulum terintegrasi dengan ciricirinya sebagai berikut: 15

1. Pengelompokan mahasiswa secara fleksibel;

2. Semua mahasiswa dituntut agar berpartisipasi secara aktif dalam proses belajar;

3. Suasana kelas berlangsung dalam suasana liberal;

4. Mengutamakan pada proses belajar;

5. Kegiatan belajar pada inquiry, discovery, problem solving;

6. Mempergunakan semua sumber belajar yang mungkin

14 Sukmadinata, Pengembangan Kurikulum:... 97

15 Oemar Hamalik, Manajemen Pengembangan Kurikulum, (Bandung: UPI dan PT Remaja Rosdakarya, 2008), 61 
menitikberatkan pada belajar pengalaman, bukan pada isi pelajaran atau metode mengajar;

7. Semua mahasiswa dididik agar kreatif

8. Mahasiswa bersikap transaktif (saling aksi dan mereaksi)

9. Mahasiswa dihadapkan pada tingkat probabilitas/kemungkinan yang menuntut pilihan

10. Hubungan di kalangan mahasiswa terarah pada pertumbuhan/ perkembangan, dimana persaingan antara kelompok dan kerjasama kelompok dapat saja dilaksanakan

11. Mahasiswa bekerja dalam bentuk self-fulfilling

12. Menekankan pada tanggung jawab, bukan keterikatan atau kebebasan mutlak

13. Mahasiswa bekerjasama dengan rekan dan dosennya.

Pembelajaran terintegrasi diawali dengan penentuan tema, karena penentuan tema akan membantu mahasiswa dalam beberapa aspek pembentukan karakter menurut Trianto yaitu: ${ }^{16}$

1. Mahasiswa yang bekerjasama dengan kelompoknya akan lebih bertanggung jawab, disiplin dan mandiri.

2. Mahasiswa menjadi lebih percaya diri dan termotivasi dalam belajar bila mereka berhasil menerapkan apa yang telah dipelajarinya.

3. Mahasiswa lebih memahami dan lebih mudah mengingat karena mereka mendengar, berbicara, membaca, menulis dan melakukan kegiatan penyelidikan masalah yang sedang dipelajarinya.

4. Memperkuat kemampuan berbahasa mahasiswa.

16 Trianto, Model Pembelajaran Terpadu, 110
5. Belajar akan lebih baik bila mahasiswa terlihat secara aktif melalui tugas proyek, kolaborasi dan berinteraksi dengan teman, dosen dan dunia nyata.

\section{Evaluasi Pendidikan Karakter Berbasis Kurikulum Terintegrasi \\ Evaluasi \\ pengembangan}

kurikulum dapat dipandang sebagai proses pembuatan keputusankeputusan tentang kurikulum di dalam kampus atau proses pembelajaran yang dibatasi oleh minat-minat pihak luar, seperti orang tua, karyawan, masyarakat lokal atau masyarakat luas. ${ }^{17}$

Peranan evaluasi kurikulum bagi pimpinan, berkenaan dengan evaluasi sebagai moral judgement, evaluasi dan penentuan keputusan, serta evaluasi dan konsensus nilai. ${ }^{18}$ Bagi guru, penyelenggaraan evaluasi hasil penerapan pengembangan kurikulum dalam satu semester, yaitu: evaluasi formatif dan evaluasi sumatif. Kedua jenis evaluasi ini dilaksanakan oleh guru dengan tujuan untuk mengetahui keberhasilan proses penerapan kurikulum di kelas. ${ }^{19}$

1. Evaluasi Formatif

Evaluasi formatif adalah evaluasi atau penilaian yang dilakukan setelah satu pokok bahasan selesai dipelajari oleh peserta didik. Evaluasi formatif terutama dimaksudkan untuk memberikan umpan balik kepada dosen mengenai keberhasilan proses belajar mengajarnya. Evaluasi formatif ini dapat dilaksanakan dengan tes tertulis maupun lisan.

\footnotetext{
17 Hamalik, Manajemen Pengembangan Kurikulum, 141

18 Sukmadinata, Pengembangan Kurikulum:... 180

19 Suharsimi Arikunto dan Lia Yuliana, Manajemen Pendidikan, (Yogyakarta: Aditya Media, 2009), 142
} 


\section{Evaluasi Sumatif}

Evaluasi sumatif adalah tes yang diselenggarakan oleh dosen setelah menempuh satu jangka waktu tertentu. Dalam pelaksanaan tes sumatif ini sering disebut dengan ujian semester. Butir-butir soal untuk tes sumatif jumlah dan kualitas tesnya harus lebih dibandingkan dengan butir tes formatif.

Adapun penilaian atau evaluasi kurikulum terintegrasi, yang dievaluasi atau dinilai lebih komprehensif yaitu penilaian pengetahuan, keterampilan, sikap dan nilai, dapat berupa Tes dan Non Tes. Instrumen penilaian yang Non Tes dapat berupa: skala sikap, daftar periksa, kuesioner, catatan anekdot, portofolio dan catatan sekolah. Sedangkan yang berupa Tes, dapat berupa Tes Lisan, Tes Perbuatan dan Tes Tulis. Tes Tulis ada dua macam, yaitu Tes Tulis Uraian dan Tes Tulis Objektif. Tes Tulis Uraian ada dua jenis yaitu Tes Uraian Tertutup/Terstruktur/Terbatas dan Tes Uraian Terbuka (seperti pendapat, opini). Sedangkan Tes Tulis Objektif terdiri dari pilihan ganda, memilih benar salah, menjodohkan, isian singkat, isian panjang dan isian khusus.

Penilaian non-tes juga dapat dilakukan dengan menganalisis masalah dan memaparkan pemecahannya (problem solving). Dalam pemaparan ini dapat ditekankan pentingnya penggunaan kosa kata yang tepat, sistematika penyajian dan pengetahuan lain untuk memecahkan masalah yang ditentukan. Bisa juga melalui observasi dan inferensi perkembangan berpikir kritis dan kreatif serta keterampilan ber-inquiry mahasiswa dapat dievaluasi.

\section{KESIMPULAN}

Membangun karakter mahasiswa yang memiliki kecakapan intektual (pengetahuan), kecakapan sikap dan karsa (emosi), dan kecakapan tindakan (motorik/keterampilan) bisa berhasil dengan pembelajaran yang berbasis kurikulum terintegrasi. Sebab kurikulum terintegrasi yang membentuk mahasiswa agar memiliki kebulatan kepribadian mahasiswa yang sesuai dengan lingkungan masyarakat dan kebutuhan bangsanya. Pembelajaran terintegrasi lebih menekankan pada kasus per kasus yang berupa tema atau topik, sehingga pembelajaran pasti menggunakan strategi problem solving. Kecakapan mahasiswa baik intektual, emosi dan tindakan akan terlatih untuk menyelesaikan masalah kehidupannya dengan karakter yang terbaik sesuai landasan bangsa dan negara Indonesia.

\section{REFERENSI}

Ali, Muhammad (2009), Pengembangan Kurikulum di Sekolah, Bandung: Sinar Baru Algensindo.

Anas, Mohamad, et.al., (2020), Berkepribadian dalam Kebudayaan Indonesia, Malang: PMPK UB.

Arikunto, Suharsimi dan Lia Yuliana, (2009), Manajemen Pendidikan, Yogyakarta: Aditya Media.

Koesoema A., Dony, (2015), Pendidikan Karakter, Utuh dan Menyeluruh, Yogyakarta: Kanisius.

Nurgiyantoro, Burhan, (1988), Dasardasar Pengembangan Kurikulum Sekolah, Yogyakarta: BPFE.

Hamalik, Oemar, (2008), Manajemen Pengembangan Kurikulum, 
Bandung: UPI dan PT Remaja Trianto, (2007), Model Pembelajaran Rosdakarya. Terpadu: Teori dan Praktek, Jakarta: Prestasi Pustaka

Rusman, (2009), Manajemen

Kurikulum, Jakarta: PT

RajaGrafindo Persada.

Samani, Muchlas dan Hariyanto, (2011), Konsep dan Model Pendidikan Karakter, Bandung: PT Remaja Rosdakarya.

Sukmadinata, Nana Syaodih, (2005), Pengembangan Kurikulum: Teori dan Praktek, Bandung: PT. Remaja Rosdakarya. 